Journal of Applied Pharmaceutical Science Vol. 5 (09), pp. 124-126, September, 2015

Available online at http://www.japsonline.com

DOI: $10.7324 / \mathrm{JAPS} .2015 .50923$

ISSN 2231-3354 (cc) BY-NC-SA

\title{
In vitro evaluation of Schima wallichii (DC.)Korth.fruit for potential antibacterial activity
}

\author{
Ankur Das Barma ${ }^{1 *}$, Jyochhana Priya Mohanty ${ }^{1}$, Prosanta Pal ${ }^{1}$, Nihar Ranjan Bhuyan ${ }^{2}$ \\ ${ }^{1}$ Department of Pharmacognosy, Himalayan Pharmacy Institute, Majhitar, East Sikkim-737136, India. \\ ${ }^{2}$ Department of Pharmaceutical Analysis \& Quality Assurance, Himalayan Pharmacy Institute, Majhitar, East Sikkim-737136, India.
}

\begin{tabular}{l} 
ARTICLE INFO \\
\hline Article history: \\
Received on: 02/07/2015 \\
Revised on: 05/08/2015 \\
Accepted on: 29/08/2015 \\
Available online: $27 / 09 / 2015$ \\
\hline Key words: \\
Schima wallichii (DC.) \\
Korth. fruit, antibacterial \\
activity, agar disc diffusion \\
assay, minimum inhibitory \\
concentration (MIC).
\end{tabular}

\section{INTRODUCTION}

In the developing countries as well as in worldwide, the most human died due to infectious bacterial diseases. The bacterial organisms including Gram positive and Gram negative like different species of Staphylococcus, Bacillus and Salmonella are the main source to cause severe infections in humans. Because these organisms have the ability to survive in harsh condition due to their multiple environmental habitats (Bibiet al., 2011). There are several medicinal plants which are having antibacterial activity are used traditionally against bacteria (Khan et al., 2012). Schima wallichii (DC.) Korth. is a well-known plant of Sikkim Himalayan region, belonging to the family Theaceae. It is 40-100ft height and distributed 2000-5000ft. in Eastern Himalayan Region. It is used as anti-inflammatory and antidote agent by the local healers (Gurung, 2002). Schima wallichii barks having anthelmintic (Dewanjee et al., 2007), antibacterial (Dewanjee et al., 2008), antinociceptive (Dewanjeeet al., 2009),

\footnotetext{
* Corresponding Author

Email: ankurdsbrm@gmail.com
}

anti-inflammatory (Dewanjee et al., 2011), antioxidant (Das et al., 2012), analgesic and antipyretic activity (Das and Ghosh, 2013). In this paper by considering the antibacterial activity of bark of Schima wallichii an attempt has taken to test the antibacterial activity of various extracts of Schima wallichii (DC.) Korth. fruits by using gram positive and gram negative bacteria.

\section{MATERIALS AND METHODS}

\section{Plant material}

Fruits of Schima wallichii (DC.) Korth. were collected from Majhitar, East Sikkim, India in the month of DecemberJanuary, 2014 and identified by Dr. Dinesh Agarwala, Scientist C, Botanical Survey of India, Sikkim Himalayan Regional Center, Gangtok, India. A voucher specimen (Accession Number 0056 \& 57 ) has been preserved at our laboratory for future reference.

\section{Preparation of the extract}

The fruits were dried under shade, pulverized into coarse powder with the help of mortar and pestle. The coarse powder was extracted with different solvent as given in protocols below: 


\section{Organic solvent extraction}

$150 \mathrm{gm}$. of coarsely shade dried powder was extracted successively first with $500 \mathrm{ml}$ of benzene and then with $500 \mathrm{ml}$ of acetone by cold maceration process. The mixtures were placed at room temperature for $72 \mathrm{hrs}$. The solutions were filtered through muslin cloth and filtered again by passing through filter paper. The filtered solutions were concentrated separately by using rotary evaporator and finally transferred to petridishes at room temperature for complete evaporation. The solvents present in liquid extracts were collected separately from the rotary evaporator and kept into bottles at $4^{\circ} \mathrm{C}$ for further use.

\section{Aqueous extraction}

$2.5 \mathrm{ml}$ of chloroform was mixed with distilled water to get a final volume of 1 litre and treated as same as the organic solvents to get dry aqueous extract.

\section{Phytochemical Screening}

Organic (Benzene \& Acetone) and aqueous extracts of Schima wallichii (DC.) Korth. fruits were containing cardiac glycosides, tannins, flavonoids, steroids and saponins by using standard procedures (Jeyaseelan and Jashothan, 2012).

\section{Bacterial strains}

The bacterial strains selected for present study were collected from Department of Pharmaceutical Technology, Jadavpur University, Kolkata, India. A total of five bacteria namely Escherichia coli $\mathrm{HD}_{10}$; Salmonella paratyphi $\mathrm{A}_{2}$; Vibrio cholera 64; Staphylococcus aureus NCTC 8530 and Bacillus liherfernis 10341 were screened for present investigation. The first three were Gram-negative and remaining were Gram-positive bacteria.

These bacterial cultures were maintained in nutrient agar slants at $37^{\circ} \mathrm{C}$. Microorganisms of each type were reactivated by sub-culturing in nutrient broth media, incubated at $37^{\circ} \mathrm{C}$ overnight.

\section{Antibacterial activity}

In-vitro antibacterial susceptibility test was carried out by disc diffusion method against 2 Gram-positive (Staphylococcus aureus NCTC 8530 and Bacillus liherfernis 10341) and 3 Gramnegative bacteria (Escherichia coli $\mathrm{HD}_{10}$; Salmonella paratyphi $\mathrm{A}_{2}$ and Vibrio cholera 64). The turbidity of bacterial suspension in Mueller Hinton Broth (Himedia, India) was adjusted to McFarland standard number 0.5 . With a sterile cotton swab bacterial culture was streaked on previously prepared Mueller Hinton agar plate (Himedia, India).The dried and sterilized filter paper discs were treated separately with desired concentration of previously prepared organic and aqueous solution of the root extract using a micropipette. Then it was dried in air under aseptic condition and placed at equidistance on a circle of the seeded plate. The concentrations of fruit extract used were $100 \mu \mathrm{g} / \mathrm{disc}, 150 \mu \mathrm{g} / \mathrm{disc}$, $200 \mu \mathrm{g} /$ disc, $250 \mu \mathrm{g} / \mathrm{disc}, 300 \mu \mathrm{g} /$ disc. These plates were kept for
4-6 hours at low temperature to diffuse the test materials from disc to the surrounding medium and then incubated at $37^{\circ} \mathrm{C}$ for 24 hours.

The diameter of the zone of inhibition produced by the fruit extract was then compared with standard antibiotic Streptomycin $(100 \mu \mathrm{g} / \mathrm{disc})$. Each sample was used in triplicate for the determination of antibacterial sensitivity test. Distilled water and DMSO soaked discs were used as negative control (Fakruddin et al., 2012).

\section{Statistical analysis}

The values of antibacterial sensitivity test of the different extracts of Schima wallichii (DC.) Korth. fruits were expressed as mean \pm standard deviation $(\mathrm{n}=3)$ for each sample (Rao et al., 2010).

\section{RESULTS}

Predictions of antibacterial activity in herbal compounds extracted from plant parts depend largely upon the type of solvent used for extraction. This fruit extracts were containing cardiac glycoside, tannin, flavonoid, steroid and saponin which is identified by the Preliminary phytochemical screening.The benzene, acetone and aqueous extract of Schima wallichii (DC.) Korth. fruit exhibited the antibacterial activity against 5 bacterial strains (table 1) and the result were expressed as mean \pm standard deviation $(n=3)$. Among the various extract acetone extract showed maximum antibacterial activity. The antibacterial activity of acetone extract was highest against Escherichia coli $\mathrm{HD}_{10}$ (14.9 \pm 0.200$)$, moderate against Bacillus liherfernis $10341(14.8 \pm 0.264)$ and lowest in case of Staphylococcus aureus NCTC $8530(13.43 \pm 0.351)$ as compared with streptomycin as positive control and negative Control as distilled water and DMSO (Dimethyl sulfoxide).

Active extracts thus obtained (fruits extracts prepared in organic and aqueous solvents) were further subjected for determination of minimum inhibitory concentration (MIC) by twofold micro broth dilution method against susceptible bacterial species viz., Gram-positive (Staphylococcus aureus NCTC 8530 and Bacillus liherfernis 10341) bacteria and Gram-negative (Escherichia coli $\mathrm{HD}_{10}$; Salmonella paratyphi $\mathrm{A}_{2}$ and Vibrio cholera 64) bacteria. Table 2 indicated that acetone extract was found significant inhibitor than other extracts. MIC of this extract were $100 \mu \mathrm{g} / \mathrm{ml}, 150 \mu \mathrm{g} / \mathrm{ml}$ against gram negative Escherichia coli $\mathrm{HD}_{10}$ and Salmonella paratyphi $\mathrm{A}_{2}$ respectively, while it was $100 \mu \mathrm{g} / \mathrm{ml}$ and $150 \mu \mathrm{g} / \mathrm{ml}$ against other two Gram-positive bacteria Staphylococcus aureus NCTC 8530 and Bacillus liherfernis 10341 respectively.

The concentration of acetone extract tested was not enough to inhibit Vibrio cholera 64. The other extracts like benzene and aqueous extracts with MIC ranging between 200 $\mu \mathrm{g} / \mathrm{ml}$ and $300 \mu \mathrm{g} / \mathrm{ml}$ showed inhibitory activity against both Gram-positive and Gram negative bacteria. 
Table 1: In vitro antibacterial activity of organic and aqueous extracts of Schima wallichii(DC.)Korth.fruit

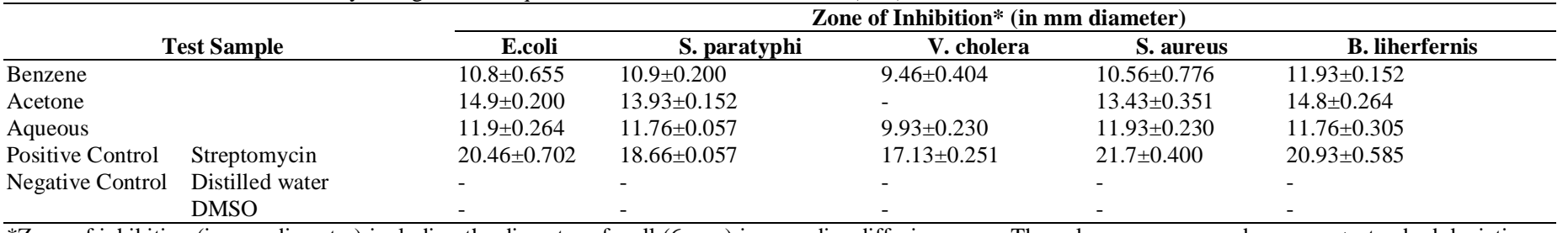

*Zone of inhibition (in mm diameter) including the diameter of well $(6 \mathrm{~mm})$ in agar disc diffusion assay. The values are expressed as mean \pm standard deviation $(\mathrm{n}=3)$ for each sample.

Microorganisms: E.coli-Escherichia coli $\mathrm{HD}_{10}$; S.paratyphi-Salmonella paratyphi $\mathrm{A}_{2}$; V.cholera-Vibrio cholera 64; S.aureus-Staphylococcus aureus $\mathrm{NCTC} 8530$; B.liherfernis-Bacillus liherfernis 10341.

Table. 2: Minimum inhibitory concentration (MIC) of Schima wallichii(DC.)Korth.fruit extracts

\begin{tabular}{|c|c|c|c|c|c|}
\hline \multirow[b]{2}{*}{ Extract Type } & \multicolumn{5}{|c|}{ Minimum Inhibition Concentration $(\mu \mathrm{g} / \mathrm{ml})$} \\
\hline & E.coli & S. paratyphi & V. cholera & S. aureus & B. liherfernis \\
\hline Benzene & 300 & 250 & 200 & 250 & 200 \\
\hline Acetone & 100 & 150 & ND & 100 & 150 \\
\hline Aqueous & 200 & 250 & 300 & 200 & 250 \\
\hline
\end{tabular}

ND-Not Detected

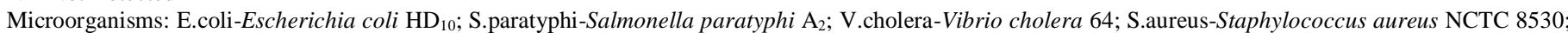

B.liherfernis-Bacillus liherfernis 10341.

\section{DISCUSSION}

In present study a variety of Gram positive and Gram negative bacteria strains were selected for the screening of antibacterial effect of benzene, acetone and aqueous extract of Schima wallichii (DC.) Korth. fruit to perceive the antibacterial spectrum. The results of this study showed that the fruit extracts of Schima wallichii (DC.) Korth. is active against both Gram positive and Gram negative bacterial strains, which may be indicative of the presence of broad spectrum chemical compounds in this extracts. So in future modern genera may be benefited by using this plant fruits.

\section{CONFLICT OF INTEREST}

The authors declare no conflict of interest.

\section{ACKNOWLEDGEMENT}

The authors are very grateful to Department of Pharmaceutical Technology, Jadavpur University and Department of Pharmacognosy, Himalayan Pharmacy Institute for providing necessary facilities and helps for this research work.

\section{REFERENCES}

Bibi Y., Nisa S., Chaudhary F.M., Zia M. Antibacterial activity of some selected medicinal plants of Pakistan. BMC Complementary and Alternative Medicine, 2011, 11:52.

Das S., Bala A., Bhowmik M., Ghosh L.K. Attenuation of reactive nitrogen species by different flavonoids enriched fractions of Schima wallichii. Asian Pacific Journal of Tropical Biomedicine, 2012, S632-S636.

Das S., Ghosh L.K. Evaluation of Analgesic, Antipyretic and Anti Inflammatory Activity of Different Fractions of Schima wallichii bark. Pharmacologia, 2013, 400-403.
Dewanjee S., Maiti A., Kundu M., Mandal S.C. Evaluation of Anthelmintic Activity of Crude Extracts of Diospyrosperegrina, Cocciniagrandis and Schima wallichii. Dhaka University Journal of Pharmaceutical Sciences, 2007, 6(2), 121-123.

Dewanjee S., Maiti A., Majumdar R., Majumdar A., Mandal S.C. Evaluation of Antibacterial Activity of Hydroalcoholic Extract Schima wallichii Bark. Pharmacologyonline, 2008, 1, 523-528.

Dewanjee S., Maiti A., Sahu R., Dua T.K., Mandal S.C. Study of anti-inflammatory and antinociceptive activity of hydroalcoholic extract of Schima wallichii bark. Pharmaceutical Biology, 2009, 47(5), 402-407.

Dewanjee S., Mandal V., Sahu R., Dua T.K., Manna A., Mandal S.C. Anti-inflammatory activity of a polyphenolic enriched extract of Schima wallichii bark. Natural Product Research, 2011, 25(7), 696-703.

Fakruddin M., Mannan K.S.B., Mazumdar R.M., Afroz H. Antibacterial, antifungal and antioxidant activities of the ethanol extract of the stem bark of Clausenaheptaphylla. BMC Complementary and Alternative Medicine, 2012, 12, 232

Gurung B. 2002. The Medicinal Plants of The Sikkim Himalayan. Jasmin Bijoy Gurung Publisher. Sikkim. 353.

Jeyaseelan E.C., Jashothan P.T.J. In vitro control of Staphylococcus aureus (NCTC 6571) and Escherichia coli (ATCC 25922) by Ricinus communis L. Asian Pacific Journal of Tropical Biomedicine, 2012, 2(10), 717-721.

Khan A.V., Ahmed Q.U., Shukla I., Khan A.A. Antibacterial activity of leaves extracts of Trifolium alexandrinum Linn. against pathogenic bacteria causing tropical diseases. Asian Pacific Journal of Tropical Biomedicine, 2012, 2(3), 189-194.

Kumar G., Karthik L., Rao K.V.B. Antibacterial Activity of Aqueous Extract of Calotropis gigantean Leaves- An In vitro Study. International Journal of Pharmaceutical Sciences Review and Research, 2010, 4(2), 141-144.

\section{How to cite this article:}

Barma AD, Mohanty JP, Pal P, Bhuyan NR. In vitro evaluation of Schima wallichii (DC.)Korth.fruit for potential antibacterial activity. J App Pharm Sci, 2015; 5 (09): 124-126. 